\title{
Questões de texto e cena
}

\author{
Isa Etel KOPELMAN ${ }^{1}$ \\ Universidade Estadual de Campinas - Unicamp
}

Um texto teatral é um discurso que revela um fenômeno poético/emocional, com um lastro de uma cena imaginária, da qual derivamos situações, imagens, gestos, os possíveis significados. Provavelmente a leitura de um texto dramático, especialmente do texto dramático canônico, seja um ato de apropriação/devoração. Seguimos as pistas da obra e associamos às nossas vivências. Seguramente, desde seu surgimento, o relato dramático, a narrativa já "avistada" no texto e efetivamente vista no Theatron, lançava ao espectador/receptor a sua parcela de decifração da obra.

Em uma perspectiva histórica, a dramaturgia teatral, o modo como a textualidade é elaborada, o modo como a informação é transmitida corresponde a um desejo, a uma estética, a uma necessidade explícita do autor no contexto de sua época e ao caráter específico de escrita que, pelo menos até o final do século XIX, indiciava uma tendência espetacular. Considerada como elemento distinto da cena, enquanto elaboração da palavra e da língua, a textualidade dramática - suporte da relação que se estabelece entre o autor e seu leitor - pertence a uma ordem de discurso artístico no qual a situação cênica reverbera nas flutuações da mente.

Do ponto de vista da cena e de seus participantes/enunciadores, a leitura de um texto dramatúrgico implica inicialmente um intenso envolvimento com o universo que se oferece a nossa imaginação. Toda uma gama de sensações, procedimentos, sensibilidades é mobilizada no intuito de

\footnotetext{
${ }^{1}$ Formada pela E.A.D. e com graduação em Letras, Isa Kopelman leciona no Depto. de Artes Cênicas da Unicamp. Iniciou sua carreira em teatro e cinema como atriz e diretora, desenvolvendo paralelamente atividades didáticas em oficinas teatrais. Sua área de pesquisa é focada nas leituras contemporâneas da dramaturgia clássica (tragédia e comédia), objeto de sua dissertação de Mestrado e tese de Doutorado. E-mail: isaetel@uol.com.br.
} 
materializar no espaço um acontecimento tão efêmero. É sempre um processo ilusório de deformação de sentidos. Conduzidos por deuses invisíveis, incorporamos imagens, enunciamos falas, desencadeamos intensidades; um complexo discurso teatral vai se formulando misteriosamente no espaço. Um discurso que fala de nós, de nossa condição. No entanto, enquanto um dos elementos do fenômeno teatral, a textualidade colide, tangencia, inspira ou impregna a cena com sua poesia. Em direções variadas, buscamos um conjunto de saberes que teorizam e situam os procedimentos artísticos na perspectiva da relação texto/cena. O exame dos encontros/colisões que partem da leitura do texto à instauração de uma cena é o objeto dos comentários que se seguem.

O interesse pela visão trágica do mundo, a adesão a um sistema de valores e, sobretudo, as possibilidades inesgotáveis de exploração de uma poética cênica como o teatro grego levou-me a algumas experimentações com essa dramaturgia há algum tempo. No meu primeiro ano da Escola de Arte Dramática de São Paulo, no final da década de 1960, fui apresentada ao universo da Antiguidade grega, nas disciplinas de Mitologia e Teatro gregos, em seminários e leituras. O contato com a poética dramática da Antiguidade provocava debates apaixonados, indagações inquietantes; situava a vida em uma perspectiva grandiosa e bela. A épica heróica da Ilíada e da Odisseia descortinava uma nova forma de ver, de narrar a existência humana e sobre-humana. Despertávamos para um modo de relatar, de observar. Nesse universo de paixões heróicas, de sofrimento e compaixão, de celebração, alegria e de erotismo, tudo era nomeado, abria-se a uma explicação. Na leitura silenciosa, viajávamos pela palavra do narrador aos lugares mais variados da terra e dos deuses. Nas leituras coletivas éramos o narrador, a câmera e os personagens dessas narrativas. Percorríamos os corredores da EAD recitando aos brados a briga entre Aquiles e Agamenon:

Canta-me a cólera - ó deusa! - funesta de Aquiles Pelida, 
causa que foi de os Aquivos sofrerem trabalhos sem conta

e de baixarem para o Hades as almas de heróis numerosos

e esclarecidos, ficando eles próprios aos cães atirados e como pasto das aves. Cumpriu-se de Zeus o desígnio desde o princípio em que os dois, em discórdia, ficaram cindidos, (HOMERO, c. I.)

$\mathrm{Na}$ tradição escolar o show dos calouros parodiava tragédias. Como certas falas trágicas dos coros e dos protagonistas pronunciadas nas aulas de dicção não cabiam mesmo em nossas embocaduras, caprichávamos no tom elevado da enunciação, acrescentando às formas empostadas as vivências do dia-a-dia. Inadvertidamente atuávamos em um "clima" de comédia antiga, pelo menos no que se refere ao espírito metateatral da comédia Antiga.

Porém, mais dedicados à valorização do drama sério, trabalhávamos arduamente na impostação elevada e solene dos textos trágicos. Nossa querida professora de dicção, Milene Pacheco, nos aconselhava a pedir "uma média e um pão com manteiga" na padaria diante da escola como se fôssemos nada mais, nada menos do que reis e rainhas. "Era para que essa nova embocadura ficasse natural", afirmava ela. Um pouco depois, ainda na EAD, interpretei Cassandra no que deveria ser uma tragédia - As Troianas - escrita e dirigida pelo Dr. Alfredo Mesquita, fundador, diretor e professor da Escola. Nesse drama trágico, minha Cassandra ficava postada ao fundo central da cena, debruçada sobre uma pira, vaticinando quase que ininterruptamente a ruína de Tróia para sua família. Ela tentava em vão advertir Príamo dos males que estavam por vir. Em certo momento da cena, eu, muito concentrada na função de profetizar, pronunciei meu primeiro protesto trágico: "Esse é o destino de quem não escuta as advertências de Apolo!" O retorno do público foi imediato: uma explosão de gargalhadas, contrariando todas as expectativas. As risadas não se aplacaram no decorrer das cenas, nem eu desisti de ser atriz. Fiquei até contente pela reação 
dos espectadores; se eles não choravam, pelo menos riam; melhor que nada. Até hoje, reputo aquele descompasso à dramaturgia da peça...

Nem tudo era paródia. Ficávamos realmente impressionados, comovidos e aterrorizados com a dimensão daqueles heróis; almejávamos descobrir em nós algo de suas intensidades; algo que nos autorizasse afirmar em cena a face humana do personagem. Talvez o terror e a piedade, a comoção provocada pelos personagens, a extensão de suas ações fosse o próprio impedimento de uma descoberta das emoções mais selvagens em nós mesmos.

Ainda nessa época tive a oportunidade de assistir à encenação de uma "verdadeira" tragédia grega, em grego: o Hipólito de Eurípides, encenado pelo Teatro Grego de Pireu e apresentado no Teatro Municipal de São Paulo. Essa intrigante montagem não correspondia a nenhuma referência teatral que eu pudesse ter até então: sobre o palco, um praticável de aproximadamente $4 \mathrm{~m}$ por $3 \mathrm{~m}$ e um metro e meio acima do chão, situado em diagonal na lateral frontal esquerda do palco; uma escada ao fundo visível ao público dava para o palco maior. Esse pequeno palco era quase completamente despojado, a não ser por dois altares, respectivamente de Ártemis e Afrodite. Sobre o altar de Ártemis, um escudo; no outro a atriz/Afrodite iniciava a peça. A atriz que atuava nesse papel era a mesma que iria surgir depois, ao final da peça, como Ártemis, advertindo Teseu de seu engano. A peça começava com Afrodite deixando seu altar e se encaminhando à boca de cena (do palco menor) em uma semidiagonal com o público. Dali ela pronunciava sua fala situando a ação da peça, em grego sem legendas, e anunciando suas intenções de vingança. A seguir, no nível mais baixo e ocupando todo o espaço do palco maior, surgia um estupendo coro de mulheres dançando e entoando versos, ao som de uma percussão. Embora composto por vozes femininas, o coro já entrava assumindo o papel de Séquito de Hipólito. A lembrança dessa 
apresentação é indescritível, como se fosse um evento onírico. No nível do palco maior, Hipólito, de passagem, contracenava com o coro e saía. As cenas dos protagonistas praticamente aconteciam no palco superior. Ali, com poucos grandes gestos, os atores enunciavam suas cenas praticamente imóveis, como em um recitativo. Nos confrontos viravam um pouco o corpo em direção do antagonista. A economia de gestos, a quase imobilidade dos protagonistas, a sonoridade de suas falas, se contrapunha à mobilidade, sonoridade da rítmica e dinâmica coral que nos transportava, nós público, a uma dimensão artística que eu nunca havia experimentado anteriormente.

Quase vinte anos depois, tendo percorrido uma carreira de atriz, premiada, recebi uma bolsa de artista pela Capes/Fundação Fulbright, na Universidade de Nova Iorque NYU. Nesta Universidade freqüentei cursos em dois institutos, o Experimental Theatre Wing e o Tisch School of Arts. Do último, destaco um curso teórico/prático de elaboração performática e, como trabalho de final de curso, um roteiro de performação com a primeira tragédia da Oréstia, o Agamenon de Ésquilo de uma edição portuguesa que eu trouxera comigo do Brasil. Eu morava no Brooklyn e, às vezes, caminhava até a ilha de Manhattan, percorrendo a região baixa da ilha, sob a ponte do Brooklyn. Ali havia muitos galpões abandonados, imensos, muitos deles semidestruídos. Eram lugares meio fantasmagóricos, onde as figuras humanas ficavam diminutas diante da escala monumental desses edifícios: locações perfeitas para as cenas grandiosas de Agamenon:

Agamenon desembarca de navio com os produtos de seus saques. /Ele traja vestes militares./ Imigrantes miseráveis também saem desse barco./ Cassandra histérica resiste aterrorizada na rampa de saída do navio./ Ela não quer entrar no galpão a sua frente;/ assediada pelo povo que não compreende o que ela diz: Corifeu - Anda, infeliz, deixa o carro. Cede ao Destino e experimenta um jugo inevitável.

Cassandra - Ai! Ai! Céus! Terra! Apolo! Apolo!

Corifeu - Porque gemes assim invocando Lóxias? Ele não se invoca com fúnebres lamentos...

Cassandra - Ai! Ai! Céus! Terra! Apolo! Apolo! 
Corifeu - E chama de novo, num gemido triste, o deus a quem não fica bem escutar lamentos.

Cassandra - Apolo! Apolo! Deus dos caminhos! - e a mim me perdeis?!...Pela segunda vez tão facilmente me perdeis?!...

Corifeu - Parece vaticinar a própria desventura. O sopro da divindade perpassa na sua alma de escrava!

Cassandra - Apolo! Apolo! Deus dos caminhos - e a mim me perdeis?!... Aonde me trouxeste? Ai! A que morada?!...

Corifeu - À dos Atridas... Asseguro-te se não sabes.

Cassandra - Ai! Para uma casa odiada dos deuses, cúmplice de tantos assassínios e mortandades, de cabeças degoladas, matadouro humano encharcado de sangue!...

Corifeu - A estrangeira parece ter faro de cadela. Fareja e há de encontrar sangue...

Cassandra - Ah! Eu creio nestes testemunhos. Aquelas criancinhas a chorar sob o ferro, as suas carnes e membros assados a serem devorados pelo pai...

Coro - Já sabemos do teu renome de profetiza, mas não precisas menos de adivinho!

Cassandra - Ai! Deuses! Que se está tramando? Que dolorosa e nova desgraça, que pesado e irremediável crime se prepara no palácio para seus moradores? - e o socorro está tão longe...

Corifeu - Não sou capaz de compreender o que ela vaticina; o resto já eu sabia, toda gente o proclamava.

Cassandra - Ah! Miserável! Atreves-te! Então? Banhando o esposo que partilha o teu leito... - como calcular o desfecho? - Vai acontecer depressa: dois braços que se estendem, um depois do outro para ferir!...

Cassandra - Ah! Olha! Olha! Retira-te da vaca! Apanhou na cilada dum véu o touro de negros chifres e o fere! E ele cai na banheira enganadora e assassina...

Cassandra - Ai! Catástrofe, catástrofe da minha pátria para sempre perdida...

....Cassandra - O oráculo não mais voltará a mostrarse por detrás de véus, como jovem desposada. Irá antes brilhar num salto fulgurante, ante o despontar do sol, de modo a banhar, com sua luz, outra onda duma desgraça muito mais terrível ainda. Já não vos falarei por enigmas.

Sede testemunhas de como eu farejei numa carreira direta, a pista dos crimes aqui outrora cometidos. Jamais abandona este palácio um coro de vozes uníssonas, mas desarmonioso, porque nunca tem palavras amáveis. O bando festivo das Erínias desta raça bebeu sangue humano para ganhar mais desassombro, e continua no palácio sem que ninguém o possa desalojar! 
Instaladas no palácio, entoam o canto da fatalidade primeira, quando foi maculado o leito dum irmão, leito cruel para quem o manchou. Como flecheiro, errei ou atingi o alvo? Ou seria eu falsa adivinha que anda a bater de porta em porta?

Corifeu - ...Mas admiro-te, pois criada além do mar, com outra linguagem, tudo sabes como se estivesses presente.

Cassandra - A leoa de dois pés que dormia com o lobo, na ausência do nobre leão vai me matar, pobre de mim! Preparando o veneno, mistura também na taça da vingança o meu salário. Afia o punhal para o esposo e vangloria-se de lhe dar a morte por me ter trazido.

Por que continuar então com estas insígnias irrisórias, o bastão e as fitas fatídicas a cingir-me o colo?

(Parte o bastão augural e arranca as fitas, pisando-as)

Sede malditos! Olha! O próprio Apolo me despe o manto profético - mas depois de me achincalhar, unanimemente ridicularizada, com tais adornos, e para nada... Tive de suportar o insulto de "vagabunda" como se fosse miserável mendiga, a morrer de fome, que andasse a ler sinas.

Em vez duma hospedagem junto ao altar paterno, espera-me um cepo de cozinha, ensopado no sangue palpitante da minha degolação!

Mas porque gemo assim cheia de compaixão por mim mesma? Vamos cheia de intrepidez afrontar a morte, pois os deuses juraram um solene juramento.

(Dirige-se ao Palácio)

Saúdo nestas portas as portas da outra vida, e não desejo mais que um golpe certeiro, de modo que, em mortais golfadas de sangue, cerre as pálpebras, sem convulsões.

Ah! Estrangeiros... Eu não estou como a ave que pia assustada ante o arbusto. Peço-vos só que depois da minha morte, de tudo isto deis o vosso testemunho por mim, quando em expiação de mim, mulher, cair morta outra mulher, e em expiação de um pobre esposo, cair morto outro homem. Eis o presente de hospedagem que vos peço ao morrer!

Agamenon é induzido a percorrer o tapete vermelho e entrar no galpão que se encontra a sua frente:/ um lugar termal com vapores... /Inicialmente, o público acompanha a cena que acontece no pier. / Clitemnestra permanece à entrada do galpão./ Cassandra seguirá Agamenon, não antes de resistir./ Antes de seguir para sua morte ela deve invocar: "Sol! Escapulário dos mortos!" I Os miseráveis que viajaram com Agamenon vão passando quase em fila, experimentando a sensação gloriosa de pisar no tapete vermelho./ Mal isso acontece, o bando que saiu do navio é obrigado a entrar em outro barco pela polícia / Eles desaparecem na linha do horizonte./ O público entra no grande galpão por curiosidade do que está acontecendo./ O galpão, 
enorme, está vazio, a não ser por um aparelho de sauna doméstica que produz vapor;/ Ouve-se wivos de boi./ Há um clima de expectativa./ FIM. (ÉSQUILO, 2007: pp. 74-89)

Em uma perspectiva teatral artística, o ato de ler um texto significa o exercício de uma arte, de um ofício que relaciona o material escrito à matéria da vida. Os relatos acima, ainda que anedóticos, descrevem meu interesse pela dramaturgia grega e, sobretudo, ilustram um modo teatral específico de se impregnar da literatura dramática e/ou do universo da obra. Meu processo de apropriação da dramaturgia grega projeta um corpo em um espaço que imanta uma cena; a cena que se desenvolve no decorrer de seu processo no espaço. Associo minha trajetória artística ao processo descrito por Aristóteles, referindo-se à jornada atribulada empreendida pelo iniciante dos mistérios órficos. Aristóteles afirmava que o iniciante não "aprendia" (mathein), porém "experimentava" (pathein) para passar por uma mudança de estado mental (diathenai), e a imagem da jornada da tribulação para a salvação era em parte uma metáfora de uma mudança na natureza do iniciante. Aliás, essa jornada é tematizada em $A s r a s^{2}$, de Aristófanes.

A narrativa de $A s$ rãs se desenrola em um contexto de religiosidade e comicidade. O coro de rãs barulhentas que zelam pelo templo de Dionísio nas águas pantanosas é ao mesmo tempo engraçado e solene; o coro principal dos iniciados nos ritos eulesinos, com seus transes, cantos e danças tem um duplo caráter de transcendência e escatologia. O caráter rapsódico da música composta para o espetáculo destacava esses dois eixos de transcendência e comicidade. Em As rãs, mantivemos o caráter picaresco das peripécias que acontecem durante o percurso da descida de Dionísio e de seu escravo Xantias (desdobrado por dois atores) ao Hades. Em cena, uma conjunção de comicidade, solenidade épica e estranheza coloriam os acontecimentos e as

\footnotetext{
2 Aristófanes (2004, pp. 187-274).
} 
imagens da peça; uma mistura híbrida de estilos que transitavam da imponência elevada e solene à breguice e escatologia deslavada da cultura popular. As disputas dos dois poetas aconteciam sobre o equiclema (um pequeno palco introduzido na cena) que funcionava em um cabaré de beira de estrada. A discussão começava em tom de paródia, de teatro de circo, em meio aos shows de dança e canto, e terminava em um tom concentrado, intimista, sério. Eurípedes era apresentado por um ator e Ésquilo por uma atriz.

$\mathrm{Na}$ cena aristofânica, os acontecimentos contingentes, as sátiras ferinas dos fatos sociais e os personagens históricos reais são parte integrante das tramas. A obra de Aristófanes é um vasto mural no qual concorrem o coro, a musicalidade da cena, os personagens, as situações, os diálogos, as inversões de sentido, o meta-teatro. As derrisões aristofanescas da épica afirmam sempre e constantemente o tempo presente da sátira jubilosa. Tudo aquilo que constituiu o espírito, o ânimo e a dinâmica social dos atenienses, dos acontecimentos políticos e sociais às idéias e aos costumes, das novidades poéticas e orquestrais aos gostos da época se revela, ainda hoje, uma mina inesgotável de prazeres de todos os tipos.

Ainda assim, o texto, em relação à encenação do presente, só é possível à custa de um sentimento de estranhamento que leva o texto a derivar para outras direções do suposto sentido original. Consequentemente, a leitura de um texto clássico requer alguns critérios de recepção. São critérios que testemunham como esse texto é recebido e percebido na atualidade. Nesse processo, a participação do receptor, destinatário da obra, é fundamental para a construção dos sentidos que mantêm a obra circulando na vida.

\section{BIBLIOGRAFIA CITADA:}

ARISTÓFANES. As rãs. Trad. e notas de Mario da Gama Kury. Rio de Janeiro: George Zahar Ed., 2004.

CORVIN, Michel. "L'Ésprit du lieu”. In: THÉÂTRE/PUBLIC. JuilletOctobre. pp. 36-52. 
ÉSQUILO. Agamémnon. Trad, introd e notas Trajano Vieira. São Paulo: Perspectiva, 2007.

HOMERO. Ilíada. Trad. em versos de Carlos Alberto Nunes. Rio de Janeiro: Ediouro, 2001.

PAVIS, Patrice. A análise de espetáculos. São Paulo, Editora Perspectiva, 2008.

PICKARD, Arthur. The theatre of dyonisius in Athens. Oxford, Oxford at the Claredon Press, 1946.

Abstract: This paper enlightens some classic plays interpretations and their different staging possibilities.

Keywords: textual qualities; play-writing; Greek poetics; value system; imagination; scene. 